University of Nebraska - Lincoln

DigitalCommons@University of Nebraska - Lincoln

U.S. Environmental Protection Agency Papers

U.S. Environmental Protection Agency

1998

Induction of Oxidative Stress in Brain Tissues of Mice after Subchronic Exposure to 2,3,7,8-Tetrachlorodibenzo-p-dioxin

\author{
Ezdihar A. Hassoun \\ College of Pharmacy, University of Toledo, Toledo, Ohio \\ Shawn C. Wilt \\ College of Pharmacy, University of Toledo, Toledo, Ohio \\ Michael J. Devito \\ National Health and Environmental Effects Research Laboratory, U.S. Environmental Protection Agency, \\ Research Triangle Park, North Carolina \\ Angelique Van Birgelen \\ Research Triangle Park, North Carolina \\ Naser Z. Alsharif \\ Creighton University, 2500 California Plaza, Omaha, Nebraska \\ See next page for additional authors \\ Follow this and additional works at: https://digitalcommons.unl.edu/usepapapers \\ Part of the Civil and Environmental Engineering Commons
}

National Health and Environmental Effects Research Laboratory, U.S. Environmental Protection Agency,

Hassoun, Ezdihar A.; Wilt, Shawn C.; Devito, Michael J.; Van Birgelen, Angelique; Alsharif, Naser Z.; Bimbaum, Linda S.; and Stoh, Sidney J., "Induction of Oxidative Stress in Brain Tissues of Mice after Subchronic Exposure to 2,3,7,8-Tetrachlorodibenzo-p-dioxin" (1998). U.S. Environmental Protection Agency Papers. 44.

https://digitalcommons.unl.edu/usepapapers/44

This Article is brought to you for free and open access by the U.S. Environmental Protection Agency at DigitalCommons@University of Nebraska - Lincoln. It has been accepted for inclusion in U.S. Environmental Protection Agency Papers by an authorized administrator of DigitalCommons@University of Nebraska - Lincoln. 


\section{Authors}

Ezdihar A. Hassoun, Shawn C. Wilt, Michael J. Devito, Angelique Van Birgelen, Naser Z. Alsharif, Linda S. Bimbaum, and Sidney J. Stoh 


\title{
Induction of Oxidative Stress in Brain Tissues of Mice after Subchronic Exposure to 2,3,7,8-Tetrachlorodibenzo-p-dioxin
}

\author{
Ezdihar A. Hassoun, Shawn C. Wilt, Michael J. Devito,* Angelique Van Birgelen,* Naser Z. Alsharif, $\dagger$ \\ Linda S. Birnbaum, ${ }^{*}$ and Sidney J. Stohs ${ }^{\dagger}, 1$ \\ College of Pharmacy, University of Toledo, Toledo, Ohio 43606; *National Health and Environmental Effects Research Laboratory, \\ U.S. Environmental Protection Agency, Research Triangle Part, North Carolina 27711; and †School of Pharmacy and \\ Allied Health Professions, Creighton University, 2500 California Plaza, Omaha, Nebraska 68178
}

Received June 24, 1997; accepted November 30, 1997

Induction of Oxidative Stress in Brain Tissues of Mice after Subchronic Exposure to 2,3,7,8-Tetrachlorodibenzo-p-dioxin. Hassoun, E. A., Wilt, S. C., Devito, M. J., Van Birgelen, A., Alsharif, N. Z., Birnbaum, L. S., and Stohs, S. J. (1998). Toxicol. Sci. 42, 23-27.

The ability of single doses of 2,3,7,8-tetrachlorodibenzo- $p$-dioxin (TCDD) to induce oxidative stress in hepatic and some extrahepatic tissues of animals is well documented. However, no previous study has examined the ability of TCDD to induce oxidative stress and tissue damage in brain in vivo. In this study the ability of TCDD to induce oxidative stress in brain tissues of mice was studied after subchronic exposures. Groups of female B6C3F1 mice were treated orally with TCDD $(0,0.45,1.5,15$, and 150 $\mathrm{ng} / \mathrm{kg} /$ day) for 13 weeks, 5 days/week. The animals were euthanized 3 days after the last treatment and brain tissues were collected. Biomarkers of oxidative stress including production of superoxide anion, lipid peroxidation, and DNA-single-strand breaks (SSB) were determined. TCDD treatment resulted in significant and dose-dependent increases in the production of superoxide anion as assessed by reduction of cytochrome $c$. Significant increases were also observed in lipid peroxidation and DNA-SSB in those tissues, as assessed by the presence of thiobarbituric acid-reactive substances and the alkaline elution technique, respectively. These results clearly indicate that subchronic exposure to low doses of TCDD can induce oxidative tissue damage in brain tissues which may at least in part play a role in the effects of TCDD on the central nervous system. 1998 Sackety of Torkobozy.

2,3,7,8-Tetrachlorodibenzo-p-dioxin (TCDD) is often called the most toxic man-made chemical. Despite the wide range of effects of TCDD in various animal species, the role of the central nervous system in TCDD intoxication has received relatively little attention. Data concerning the direct effects of TCDD on the central nervous system are contradictory. While studies by Pohjanvirta et al. (1989) have demonstrated a typical reduction in feed intake after slow infusion of TCDD into

\footnotetext{
' To whom correspondence should be addressed. Fax: (402) $280-5738$. E-mail: stohs $@$ creighton.edu.
}

the brain ventricles of Long-Evans and Han/Wistar rats, these findings could not be replicated in Sprague-Dawley rats (Stahl and Rozman, 1990). TCDD does not readily penetrate into the brain, and concentrations of TCDD are far lower in the brain than in the liver or adipose tissues after exposure (Pohjanvirta et al., 1990; Weber et al., 1993). However, sensitive biochemical effects, such as enzyme induction (Elovaara et al., 1977; Hook et al., 1975, Unkila et al., 1993, 1995) and changes in the concentrations of selected neurotransmitters (Russell et al., 1988; Tuomisto et al., 1990; Pohjanvirta et al., 1994), are seen in the brain after TCDD exposure.

Recent studies also demonstrate a high frequency of intercerebral asymmetry in the brains of heron hatchlings from areas environmentally contaminated with TCDD, and this effect was significantly correlated with the levels of TCDD in eggs taken from the same nest (Henshel et al., 1995). There is also preliminary evidence that TCDD may cause injury to rat hippocampal neurons in culture, as indicated by an increase in intracellular calcium (Hanneman et al., 1993).

Oxidative stress is considered an important mechanism in the toxicity of TCDD (Stohs, 1990; Stohs et al., 1991). Previous studies have shown that administration of TCDD to laboratory animals induces production of reactive oxygen species (Alsharif et al., 1994a,b; Bagchi and Stohs, 1993), lipid peroxidation (Stohs et al., 1983; Mohammadpour et al., 1988), DNA damage (Wahba et al., 1988; Alsharif et al., 1994b), and decreased membrane fluidity (Alsharif et al., 1990) following acute, high-dose exposure. TCDD administration to rats also results in significant increases in the urinary excretion of the lipid metabolites, malondialdehydc, formaldehyde, acetaldehyde, and acetone (Bagchi et al., 1993). In the current study we have shown that oxidative tissue damage can occur in the brains of mice following subchronic exposure to doses of TCDD as low as $0.45 \mathrm{ng} / \mathrm{kg} / \mathrm{day}$.

\section{MATERIALS AND METHODS}

Chemicals. 2,3,7,8-Tetrachlorodibenzo-p-dioxin was obtained from Ultra Scientific (Northkings Town, RI) and was $>98 \%$ pure. All other chemicals 


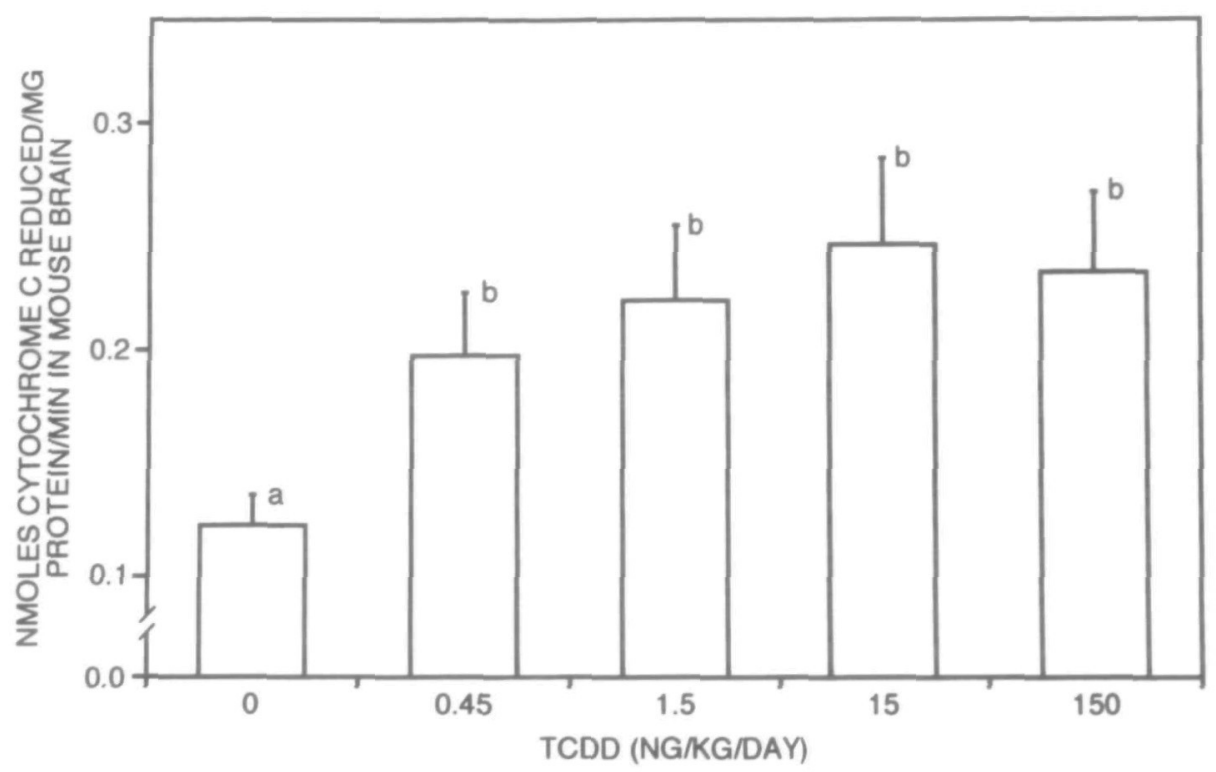

FIG. 1. Superoxide anion production by brain tussue homogenates based on cytochrome $c$ reduction, expressed as nanomoles of cytochrome $c$ reduced per milligram of protein per minute. Animals were treated with TCDD (treated groups) or the com oil vehicle (control group) for 13 weeks ( 5 days/week) and were euthanized 3 days after the last dose. Values with nonidentical letters are significantly different $(p<0.05)$.

used in this study were obtained from Sigma Chemical Co. (St. Louis, MO) and were of analytical grade or of the highest grade commercially available.

Animals and treatments. Female $\mathrm{B} 6 \mathrm{C} 3 \mathrm{FI}$ mice were obtained from Charles River (Raleıgh, NC) at 60 days of age and were maintained and treated at the U.S. Environmental Protection Agency (EPA) (Research Triangle Park, $\mathrm{NC}$ ). The animals were housed at $25^{\circ} \mathrm{C}$ with a 12 -h light/dark cycle and were given a commercial pelleted diet with tap water ad libitum. TCDD solutions were administered to the different groups of mice by gavage at doses of 0.45 , $1.5,15$, and $150 \mathrm{ng} / \mathrm{kg} /$ day for 13 weeks, 5 days/week (DeVito and Birnbaum, 1994). Control mice received the corn oil vehicle used to dissolve TCDD at 10 $\mathrm{ml} / \mathrm{kg} /$ day. The animals were euthanized 3 days after the last treatment using carbon dioxide asphyxiation, and the brains were removed and maintained over dry ice until determinatıon of oxidative tissue damage.

Sample preparation. Brain tissues from each mouse were divided into two portions, weighed, and placed either in Tris- $\mathrm{KCl}$ buffer $(0.05 \mathrm{M}$ Trns chloride and $1.15 \% \mathrm{KCl}, \mathrm{pH} 7.4)$ for lipid peroxidation and production of reactive oxygen species assays or in the homogenizing buffer of White et al. (1981) for the assay of DNA-single-strand breaks (DNA-SSB). The samples were homogenized over ice using a Potter-Elvehjem homogenizer fitted with a Teflon pestle to produce a $10 \%$ homogenate for lipid peroxidation and superoxide anion assays and a $20 \%$ homogenate for the assay of DNA-SSB. The DNA homogenates were centrifuged at $1000 \mathrm{~g}$ for $10 \mathrm{~min}$. After centrifugation, nuclear pellets were resuspended in two times the original volume of the homogenizing buffer for the determination of DNA-SSB.

Determination of lipid peroxidation. Lipid peroxidation was determined in brain tissues using the colorimetric method of Uchiyama and Mihara (1978) by measuring the formation of thiobarbituric acid-reactive substances (TBARS). Malondialdehyde was employed as the standard. The TBARS concentrations were determined spectrophotometrically on a Perkin-Elmer spectrophotometer, utilizing the differences at 535 and $520 \mathrm{~nm}$ and the molar absorptivity constant of $1.56 \times 10^{5} \mathrm{M}^{-1} \mathrm{~cm}^{-1}$.

Defermination of the production of reactive oxygen species. Production of superoxide anion in brain tissue homogenates was measured by the assay method of Babior et al. (1973), which is based on the reduction of cytochrome c collected for subsequent spectrophotometric measurement. Absorbances were monitored at $550 \mathrm{~nm}$ and converted to nanomoles of cytochrome $c$ reduced/min, using the extinction coefficient $2.1 \times 10^{4} \mathrm{M}^{-1} \mathrm{~cm}^{-1}$

Determination of DNA-single-strand breaks. DNA darnage was measured in the nuclear fractions of brain tissues as single-strand breaks by the alkaline elution method as previously described (Wahba et al., 1988) DNA contents were measured microfluorometrically (excitation $436 \mathrm{~nm}$, emissıon $521 \mathrm{~nm})$ in a Perkin-Elmer spectrofluorometer and the elution constant $(k)$ was determined by plotting the $\log _{10}$ DNA remaining on the filter after each fraction, against the volume of the eluate, where $k=-2.3 \times$ slope of this plot.

Determination of protein. Protem concentrations were determined by the method of Lowry et al. (1951), using bovine serum albumin as the standard.

Statistical methods. Data are expressed as the mean \pm standard deviation (SD). Each value was denved from seven animals. Data for each group of treated animals were compared with the control values, using analysis of variance (ANOVA) with Scheffe's S method as the post hoc test. The level of statistical significance employed in all cases was $P<0.05$.

\section{RESULTS}

The ability of various doses of TCDD to induce production of superoxide anion in brain tissues of $\mathrm{B} 6 \mathrm{C} 3 \mathrm{~F} 1$ mice after subchronic exposure is presented in Fig. 1. Significant increases in superoxide anion production, as indicated by reductions of cytochrome $c$, were observed, relative to control levels. These increases were dose dependent, being first significantly detected at $0.45 \mathrm{ng} / \mathrm{kg} /$ day compared to controls, with a plateau being observed at a TCDD dose of $15 \mathrm{ng} / \mathrm{kg} /$ day. At this dose a 2.3-fold increase in cytochrome $c$ reduction (Fig. 1) was observed.

The effect of subchronic, low-dose administration of TCDD to $\mathrm{B} 6 \mathrm{C} 3 \mathrm{~F} 1$ mice on the induction of lipid peroxidation (TBARS formation) in brain tissues is presented in Fig. 2. 


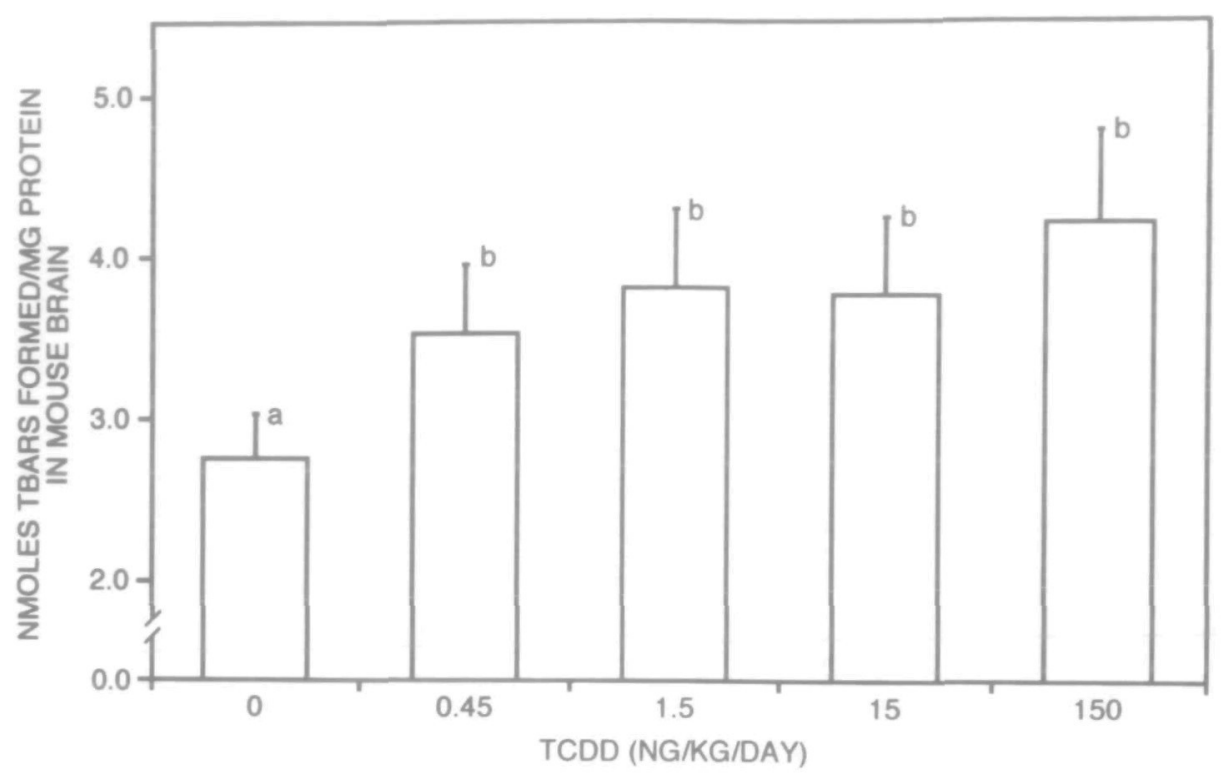

FIG. 2. Lipid peroxidation based on the formation of thiobarbituric acid reactive substances (TBARS), expressed as nanomoles of malondialdehyde (MDA) per milligram of protein. Animals were treated with TCDD (treated groups) or com oil vehicle (control group) for 13 weeks (5 days/week) and were euthanized 3 days after the last dose. Values with nonidentical letters are significantly different $(p<005)$.

Increases in lipid peroxidation were observed at all four doses relative to the control group, with a 1.4-fold increase in TBARS formation occurring at a $0.45 \mathrm{ng} / \mathrm{kg} /$ day dose of TCDD and a 1.8 -fold increase occurring at a dose of 150 $\mathrm{ng} / \mathrm{kg} /$ day.

The effect of TCDD on DNA-SSB in brain tissues of B6C3F1 mice is presented in Fig. 3. A dose-dependent increase in DNA-SSB was observed relative to the control group. At a TCDD dose of $0.45 \mathrm{ng} / \mathrm{kg} /$ day a 2.0 -fold increase in DNASSB was observed, while at $150 \mathrm{ng} / \mathrm{kg} /$ day a 3.5 -fold increase in DNA-SSB occurred.

\section{DISCUSSION}

The present studies clearly demonstrate that subchronic exposure to TCDD induces oxidative stress in brain tissues of mice as evidenced by the enhanced production of superoxide anion (Fig. 1) and the increased production of tissue damage as suggested by the induction of lipid peroxidation (Fig. 2) and DNA damage (Fig. 3). It has been shown that the brain consumes a proportionally larger amount of oxygen than other organs and has only moderate levels of both enzymatic and nonenzymatic scavengers of reactive oxygen species (Halliwell and Gutteridge, 1985). Lipid peroxidation is one of the primary effects induced by oxidative stress and may occur readily in the brain due to the presence of membranes that are rich in polyunsaturated highly oxidizable fatty acids (Cini et al., 1994). Thus, the brain may be a target organ for various chemicals such as TCDD which are known to induce oxidative tissue damage.
The results of the current study agree well with previous results demonstrating the ability of TCDD to induce production of reactive oxygen species as well as lipid peroxidation and DNA damage in hepatic and extrahepatic tissues other than brain (Stohs, 1990; Stohs et al., 1991; Mohammadpour et al., 1988; Bagchi et al., 1994; Alsharif et al., 1990, 1994a,b; Wahba et al., 1988). Oxidative stress has been demonstrated in embryonic tissues of TCDD-responsive mice and may be due to the extremely low concentrations of TCDD which are transferred to the embryos after maternal exposure to a low dose of the xenobiotic (Hassoun and Stohs, 1996; Hassoun et al., 1995).

Previous studies have involved single doses of TCDD ranging from 5 to $125 \mu \mathrm{g} / \mathrm{kg}$ in TCDD-responsive animals (Mohammadpour et al., 1988; Stohs et al., 1991; Alsharif et al., 1990; Wahba et al., 1988). The total doses received in the current study ranged from 29.25 to $9750 \mathrm{ng} / \mathrm{kg}$. The two highest doses used in the current study ( 15 and $150 \mathrm{ng} / \mathrm{kg} / \mathrm{day}$ ) cumulatively are in the range of doses previously used on a single dose basis. However, the two lowest doses which were used in the current study $(0.45$ and $1.5 \mathrm{ng} / \mathrm{kg} /$ day) are well below doses previously used to assess the ability of TCDD to induce oxidative stress and lipid peroxidation. Thus, the current results demonstrate that a dose as low as $0.45 \mathrm{ng} / \mathrm{kg} /$ day of TCDD given on a subchronic basis (13 weeks) can result in significant increases in production of reactive oxygen species as well as enhanced lipid peroxidation and DNA damage in brain tissues of mice. In mice receiving $1.5 \mathrm{ng} / \mathrm{kg} /$ day for 13 weeks, brain concentrations of TCDD were approximately 3.0 $\mathrm{pg} / \mathrm{g}$ of tissue (unpublished observations), indicating that TCDD accumulates in brain tissues and measurable quantities can be 


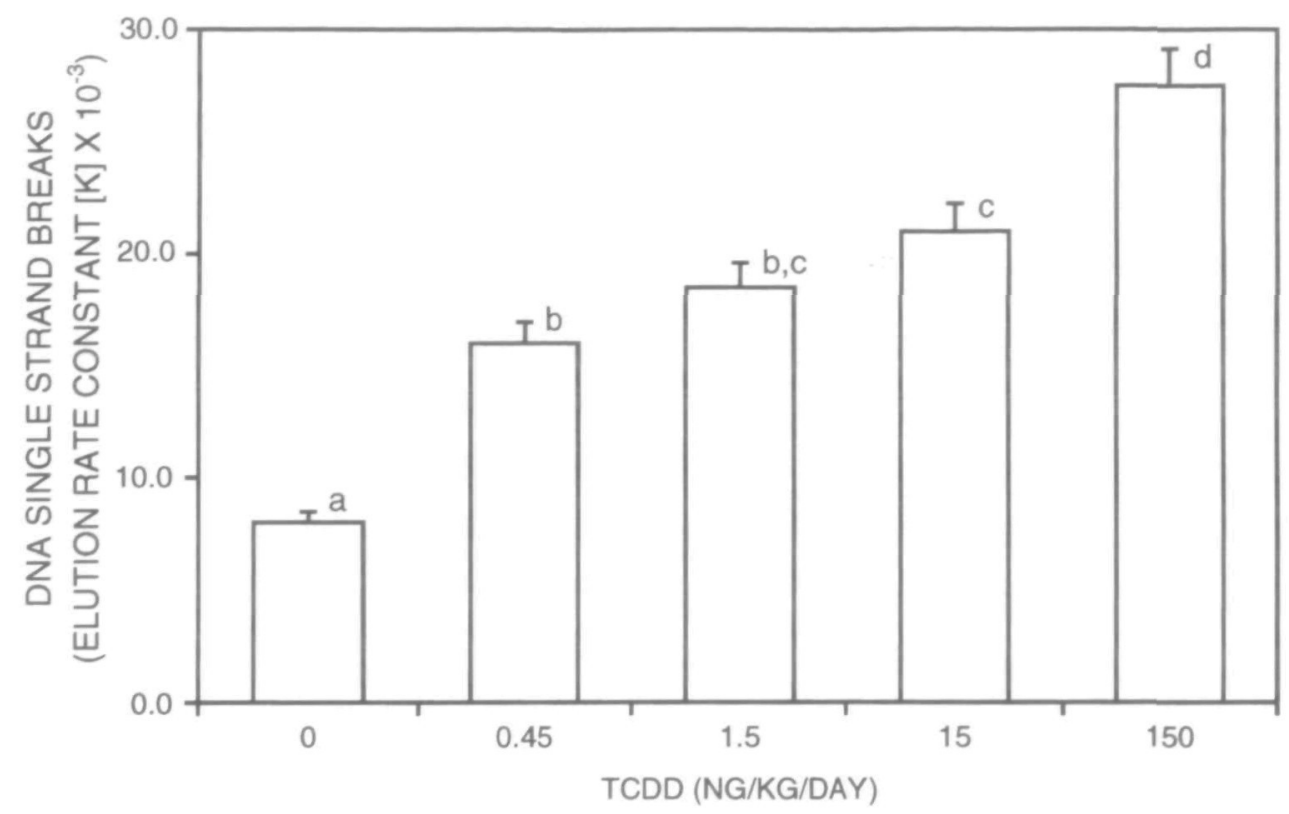

FIG. 3. DNA-single-strand breaks (SSB) were determined by the alkaline elution method and are presented as the elution rate constants $(k)$. Animals were treated with TCDD (treated group) or the corn oil vehicle (control group) for 13 weeks (5 days/week) and were euthanized 3 days after the last treatment. Values with nonidentical letters are significantly different $(p<0.05)$.

detected. Average human body burdens of TCDD in the United States are estimated at 5-10 ng TEQ/kg (De Vito et al., 1995).

Various possible mechanisms may be involved in the TCDD-induced production of reactive oxygen species in brain tissues. One of these mechanisms may involve the cytochrome P450 system. The ability of this system to produce reactive oxygen species has been well documented (Bondy and Naderi, 1994). Cytochrome $P 450$ is induced in brain tissues in response to TCDD (Unkila et al., 1995) and may therefore account for the formation of reactive oxygen species. However, additional studies will be required to correlate cytochrome P450 with the effects observed in the present study.

Another possible mechanism in the production of reactive oxygen species by TCDD may involve the induction of aldehyde dehydrogenase activity. The ability of this enzyme to generate oxygen free radicals as products of its catalytic cycle has been documented (Martinez-Cayuela, 1995). Dose-dependent increases in the activity of aldehyde dehydrogenase in brain tissue of rats are observed following in vivo treatment with TCDD at doses ranging from 5 to $50 \mu \mathrm{g} / \mathrm{kg}$ body wt (Unkila et al., 1993). This induction may contribute to overproduction of reactive oxygen species in brain tissues in response to TCDD administration. In addition, TCDD enhances production of reactive oxygen species as superoxide anion by mitochondria (Wahba et al., 1988; Stohs et al., 1991) and macrophages (Alsharif et al., 1994). Thus, multiple sites and mechanisms may be involved in the production of reactive oxygen species in response to TCDD administration.

In summary, subchronic exposure to TCDD induces production of reactive oxygen species which results in the induction of oxidative damage in brain tissues of mice as evidenced by lipid peroxidation and DNA damage. Further investigations will be required to assess the role of this mechanism in TCDDinduced biochemical changes in the central nervous system as well as functional and morphological alterations which may be produced.

\section{ACKNOWLEDGMENTS}

These studies were supported in part by a grant from the Air Force Office of Scientific Research (94-1-0048) and a research and development grant from the University of Toledo. APJMvB was supported by a grant from the Chemical Manufacturers Association. The authors thank Ms. LuAnn Schwery for technical assistance.

\section{REFERENCES}

Alshanf, N. Z., Grandjean, C. J., Murray, W. J., and Stohs, S. J. (1990). $2,3,7,8$-Tetrachlorodibenzo- $p$-dıoxin (TCDD)-induced decrease in the fluidity of rat liver membranes. Xenobiotica 20, 979-988.

Alsharif, N Z., Schlueter, W. J., and Stohs, S. J. (1994a). Stimulation of NADPH-dependent reactive oxygen species formation and DNA damage by 2,3,7,8-tetrachlorodibenzo-p-dioxin in rat peritoneal lavage cells. Arch. Environ. Contam. Toxicol. 26, 392-397.

Alsharif, N. Z., Hassoun, E., Bagchi, M., Lawson, T., and Stohs, S. J. (1994b). The effects of anti-TNF-alpha antibody and dexamethasone on TCDDinduced oxidative stress in mice. Pharmacology 48, 127-136.

Babior, B. M., Kipner, R. S., and Cerutte, J. T. (1973). Biological defense mechanism: The production by leukocytes of superoxide, a potential bactericidal agent. J. Clin. Invest. 52, 741-744.

Bagchi, D., Shara, M., Bagchi, M., Hassoun, E., and Stohs, S. J. (1993). Time-dependent effects of 2,3,7,8-tetrachlorodibenzo- $p$-dioxin on serum 
and urine levels of malondialdehyde, formaldehyde, acetaldehyde, and acetone in rats. Toxicol. Appl. Pharmacol. 123, 83-88.

Bagchi, M., and Stohs, S. J. (1993). In vitro induction of reactive oxygen species by 2,3,7,8-tetrachlorodibenzo-p-dioxin, endrin and lindane in rat peritoneal macrophages and hepatic mitochondna and microsomes. Free Rad. Biol. Med. 14, 11-18.

Bondy, S. C., and Naden, S. (1994). Contribution of hepatic cytochrome p-450 systems to the generation of reactive oxygen species. Biochem. Pharmacol. 48, 155-159.

Cini, M., Fariello, R. Y., Bianchettei, A., and Moretti, A. (1994). Studies on lipid peroxidation in the rat brain. Neurochem. Res. 19, 283-288.

Del Rio, L. A., Sandalio, L., Palma, J., Bueno, P., and Corpas, P. J. (1992). Metabolism of oxygen radicals in peroxisomes and cellular implications. Free Rad. Biol. Med. 13, 557-580.

DeVıto, M., and Birnbaum, L. S. (1994). Comparative ability of various PCBs, $\mathrm{PCDFs}$, and TCDD to induce cytochrome P450 $1 \mathrm{Al}$ and $1 \mathrm{~A} 2$ activity following 4 weeks of treatment. Fundam. Appl. Toxicol. 20, 125-130.

DeVito, M. J., Birnbaum, L. S., Farland, W. H., and Gasiewicz, T. A. (1995). Comparisons of estimated human body burdens of dioxin-like chemicals and TCDD body burdens in experimentally exposed animals. Environ. Health Perspect. 103, 820-831.

Elovaara, E., Savolainen, H., Parkki, M. G., Aitio, A., and Vainio, H. (1977). Neurochemical effects of 2,3,7,8-tetrachlorodibenzo-p-dioxin in Wistar and Gunn rats. Res Commun. Chem. Pathol. Pharmacol. 18, 487-494.

Halliwell, B., and Gutteridge, J. M. C. (1985). Oxygen radicals and the nervous system. Trends Neurosci. 8, 22-26.

Hanneman, W., Legare, M., Barhoumi, R., Wong, X., Burghardt, R., TiffanyCastiglioni, E., and Safe, S. (1993). 2,3,7,8-Tetrachlorodibenzo-p-dioxininduced elevation of intracellular calcium ions in cultured rat hippocampal neurons and astralgia in Abstracts of the 13th Intemational Symposium on Dioxins and Related Compounds, September 20-24, 1993 (Organohalogen Compounds, Vol. 13), pp. 309-312. Vienna, Austria.

Hassoun, E., Bagchi, D., and Stohs, S. J. (1995). Evidence of 2,3,7,8-tetrachlorodibenzo-p-dioxin (TCDD)-induced tissue damage in fetal and placental tissues and changes in amniotic fluid lipid metabolites of pregnant CFI mice. Toxicol. Lett. 76, 245-250.

Hassoun, E., and Stohs, S. J. (1996). TCDD, endrin and lindane-induced oxidative stress in fetal and placental tissues of C57BL/6J and DBA/2J mice. Comp. Biochem. Physiol. 115C, 11-18.

Henshel, D. S., Martin, J. W., Norstrom, R., Whitehead, P., Steeves, J. D., and Cheng, K. M. (1995). Morphometric abnormalities in brains of great blue hatchlings exposed in the wild to PCDDs. Environ Health Perspect. 103, 61-66.

Hook, G. E., Haseman, J. K., and Lucier, G. W. (1975). Induction and suppression of hepatic and extrahepatic microsomal foreign-compoundmetabolizing enzyme systems by 2,3,7,8-tetrachlorodibenzo-p-dioxin. Chem.-Biol. Interact. 10, 199-214.

Lowry, O. H., Rosebrough, N. J., Farr, W. L., and Randall, R. J. (1951). Protein measurements with the folin phenol reagent. J. Biol. Chem. 193, 265-275.

Martinez-Cayuela, M. (1995). Oxygen free radicals and human disease. Biochimie 77, 147-161.

Mohammadpour, H., Murray, W. J., and Stohs, S. J. (1988). 2,3,7,8-Tetrachlo- rodibenzo-p-dioxin (TCDD)-induced lipid peroxidation in genetically responsive and non-responsive mice. Arch. Environ. Contam. Toxicol. 17, 645-650.

Pohjanvirta, R., Hirvonen, M. R., Unkila, M., Savolainen, K., and Tuomisto, J. (1994). TCDD decreases brain inositol concentrations in the rat. Toxicol. Lert. 70, 363-372.

Pohjanvirta, R., Tuomisto, L., and Tuomisto, J. (1989). The central nervous system may be involved in TCDD toxicity. Toxicology 58, 167-174.

Pohjanvirta, R., Vartiainen, T., Uusi-Rauva, A., Mönkkönen, J., and Tuomisto, J. (1990). Tissue distribution, metabolism and excretion of ${ }^{14} \mathrm{C}$-TCDD in a TCDD-susceptible and a TCDD-resistant rat strain. Pharmacol. Appl. Toxicol. 66, 93-100.

Russell, D. H., Buckley, A. R., Shah, G. N., Sipes, I. G., Blask, D. E., and Benson, B. (1988). Hypothalamic site of action of 2,3,7,8-tetrachlorodibenzo-p-dioxin (TCDD). Toxicol. Appl. Pharmacol. 94, 496-502.

Stahl, B. U., and Rozman, K. (1990). 2,3,7,8-Tetrachlorodibenzo-p-dioxin (TCDD)-induced appetite suppression in the Sprague-Dawley rat is not a direct effect on feed intake regulation in the brain. Toxicol. Appl. Pharmacol. 106, 158-162.

Stohs, S. J. (1990). Oxidative stress induced by 2,3,7,8-tetrachlorodibenzo-pdioxin (TCDD). Free Rad. Biol. Med. 9, 79-90.

Stohs, S. J., Alsharif, N. Z., Shara, M. A., Al-Bayati, Z. A., and Wahba, Z. Z. (1991). Evidence for the induction of an oxidative stress in rat hepatic mitochondria by 2,3,7,8-tetrachlorodibenzo-p-dioxin (TCDD). Adv. Exp. Med. Biol. 283, 827-831.

Stohs, S. J., Hassan, M. Q., and Murray, W. J. (1983). Lipid peroxidation as a possible cause of TCDD toxicity. Biochem. Biophys. Res. Commun. 111, $854-859$.

Tuomisto, J., Pohjanvirta, R., McDonald, E., and Tuomisto, L. (1990). Changes in rat monoamines, monoamine metabolites and histamine after a single administration of 2,3,7,8-tetrachlorodibenzo-p-dioxin (TCDD). Pharmacol. Toxicol. 67, 260-265.

Uchiyama, M., and Mihara, M. (1978). Determination of malondialdehyde precursor in tissues by thiobarbituric acid test. Anal. Btochem. 86, 271-278.

Unkila, M., Pohjanvirta, R., Honkakoski, P., Törrönen, R., and Tuomisto, J. (1993). 2,3,7,8-Tetrachlorodibenzo-p-dioxin (TCDD)-induced ethoxy resonufin-o-deethylase (EROD) and aldehyde dehydrogenase (ALDH3) activities in the bran and liver: a comparison between the most TCDDsusceptible and the most TCDD-resistant rat strain. Bıochem. Pharmacol. 46, 651-659.

Unkıla, M., Pohjanvirta, R., and Tuomisto, J. (1995). B1ochemical effects of 2,3,7,8-tetrachlorodibenzo- $p$-dioxin (TCDD) and related compounds on the central nervous system. Int. J. Biochem. Cell Biol. 27, 443-455.

Wahba, Z. Z., Lawson, T. A., and Stohs, S. J. (1988). Induction of hepatic DNA-single strand breaks in rats by $2,3,7,8$-tetrachlorodibenzo-p-dioxin (TCDD). Cancer Lett. 29, 281-286.

Weber, L. W., Ernest, S. W., Stahl, B. U., and Rozman, K. (1993). Tissue distribution and toxicokinetıcs of 2,3,7,8-tetrachlorodibenzo-p-dioxin in rats after intravenous injection. Fundam. Appl. Toxicol. 21, 523-534.

White, R. D., Sipes, 1. G., Gandolfi, A. J., and Bowden, G. T. (1981). Characterization of the hepatic DNA damage caused by 1,2-dibromoethane using the alkaline elution technique. Carcinogenesis 2, 839-843. 